\title{
PICOSECOND SPECTROCHRONOGRAPHY STUDY OF LIGHT ENERGY UTILIZATION BY PHOTOSYNTHETIC BACTERIA.
}

\author{
(Presented by K. K. Rebane)
}

Bacteriochlorophyll (BChl) fluorescence lifetimes $(\tau)$ of purple bacteria were measured at low exciting pulse energy with the use of a picosecond fluorescence spectrochronograph of high sensitivity and high time resolution. The whole light intensity dependence of $\tau$ was followed for Rhodospirillum rubrum chromatophores from low (nearly all the reaction centres (RCs) open) to saturating light; the time interval from light absorption to excitation trapping by a RC was measured to be $50 \pm 10 \mathrm{ps}$. Selective excitation of $R$. rubrum chromatophores by light, absorbed by $\mathrm{RCs}(\lambda \approx 800 \mathrm{~nm})$ or by antenna $(\lambda=370-380 \mathrm{~nm})$ BChl, made it possible to show that excitation energy transfer in bacterial photosynthesis is a trap-limited, rather than a diffusion-limited process. The time of the primary charge separation in situ was estimated to be in the range of $10-20$ ps.

\section{Introduction}

Light quanta absorbed by photosynthetic organisms create singlet excited states of chlorophylls or accessory pigments. Due to intermolecular coupling between pigment molecules in the photosynthetic units (PSU), these excited states are not localized but are rather hopping between the molecules of the light-harvesting antenna until captured by RC. At the $\mathrm{RCs}$, excitation energy is transformed step-by-step into electrochemical energy of separated charges. It is believed that excitation energy transfer in vivo occurs via the mechanism of resonant energy transfer (for review, see $[1,2])$. This process plays an important role in photosynthesis, determining, in total, the quantum yield of sun light utilization. Despite numerous theoretical and experimental studies of energy transfer and trapping, the mechanisms of these two key photosynthetic processes are not completely understood.

A powerful experimental approach to the above problem is timeresolved fluorescence spectroscopy (see reviews $\left[{ }^{1-3}\right]$ ). The first $\tau$ measurements of the photosynthetic objects were performed with the use of the phase-shift method (described, for example, in $\left.{ }^{[2}\right]$ ) which is ruite an adequate mode for studving exponentially decaying emissions. For analysis of multicomponental emissions, some additional suppositions are needed in order to obtain the kinetics of individual components. Thus, according to $\left.{ }^{4,5}\right] . \tau$ values about $1 \mathrm{~ns}$, usually measured for nurple bacteria by the phase-shift method, do not pertain to the bulk BChl but rather to some minor long-lived component. The bulk BChl $\tau$ for RCs open was estimated to be about 50 ps. Similar data were recently obtained in $\left[{ }^{6}\right]$. Another, more direct, way of $\tau$ measurements is laser spectro- 
fluorimetry with picosecond resolution, which allows one to follow directly the whole fluorescence decay curve $\left[{ }^{7,8}\right]$. However, the first investigations performed by this method showed that the results obtained are not easily interpreted as the ultrashort light pulses used were rather intense. Thus it was hardly possible to exclude a possibility of finding simultaneously two or more excitations in PSU, especially as a number of PSUs may be interconnected at the level of excitation energy transfer. On natural conditions such situation is never realized. To overcome this difficulty a novel highly sensitive picosecond resolution spectrochronography method $\left[^{9}\right]$ as well as a single-photon timing with $\sim 0.1$ ns resolution $\left[{ }^{10}\right]$ were recently employed to follow the fluorescence decay kinetics of plant objects. Low intensity level was reliably achieved and important data obtained. However, since the objects employed contained two photosystems, the observed decay kinetics were greatly complicated by excitation energy and electron transfer interactions between them.

This work describes the results of the study of the primary steps of bacterial photosynthesis at ambient temperature with the use of a fluorescent picosecond spectrochronograph which allows measurements of fluorescence decay curves over a wide spectral range with high time and spectral resolution under conditions of very low excitation pulse energy. As a main object for the study of excitation transfer and trapping native chromatophores from purple bacterium- $R$. rubrum were selected, since this bacterium contains the simplest light-harvesting antenna with a single absorption band $B_{880}$. Parallel with the picosecond lifetime measurements, the dependence of fluorescence yield $\varphi$ and the portion of photooxidized reaction centres $\left(\mathrm{P}^{+} / \mathrm{P}_{0}\right)$ on the exciting light intensity were measured. Some preliminary results obtained on cells of sulfur purple bacterium Chromatium minutissimum are also given.

\section{Experimental}

2.1. Objects. Cells of $R$. rubrum (wild type No. $1 \mathrm{MGU}$ ) were grown and chromatophores were isolated as described elsewhere [11]. Chromatophore suspensions with an optical density of $A_{8 \times n} \mathrm{~nm} / 1 \mathrm{~cm} \approx 200$ were stored at $0^{\circ} \mathrm{C}$ under anaerobic conditions and diluted by the buffer to a final $\mathrm{BChl}$ concentration of $3-6 \cdot 10^{16}$ molecules $/ \mathrm{ml}$. The measuring solution contained $220 \mathrm{mM}$ sucrose, $50 \mathrm{mM}$ Tris- $\mathrm{HCl}$ buffer ( $\mathrm{pH} \mathrm{7.5)}$ and $2 \mathrm{mM} \mathrm{MgSO}_{4}$. Cells of Chr. minutissimum were grown in the modified Larsen's medium and used $3-5$ days after inoculation from a previous culture.

2.2. Methods. Picosecond spectrochronograph with 5 ps time and less than $1 \mathrm{~nm}$ spectral resolution in $350-1050 \mathrm{~nm}$ range $\left[{ }^{9,12,13}\right]$ is based on a combination of a «Spectra-Physics» mode locked cw oxazine 1 or oxazine 750 dye laser (tuning range $685-820 \mathrm{~nm}, 345-410 \mathrm{~nm}$ with frequency doubling, pulse duration $3 \mathrm{ps}$, average power up to $200 \mathrm{~mW}$ ) synchronously pumped with $82 \mathrm{MHz}$ by a krypton-ion laser, a doublegrating spectrometer and a streak camera (Fig. 1). A subtractive dispersion mount of spectrometer is used to narrow its pulse response with preserved luminosity up to the transform-limited value ${ }^{\left[{ }^{13}\right]}$. For data recording and processing; a EC 1010-computer-controlled B\&M. Spektronik OSA500 optical multichannel analyzer with SIT vidicon is used. Instead of commonly used pulsed deflection of streak camera, a continuous streaking in synchronism with the dye laser operation $\left.{ }^{14}\right]$ is employed. As a result, a high quality of a set of important parameters is achieved in our set-up (see Fig. 1). For measurements of $\tau$ light-intensity dependence, the analyzing monochromator was changed for narrowband interference and glass filters; in some cases a thin plate of GaAs 


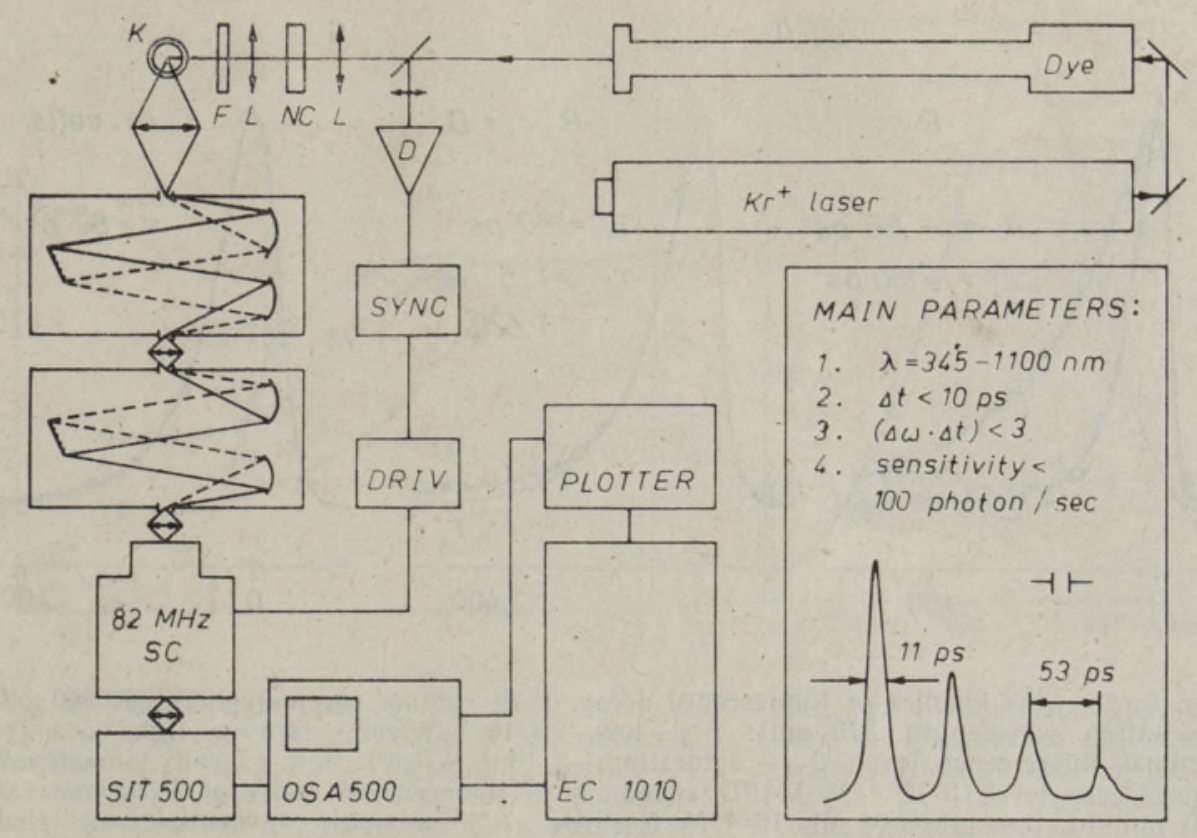

Fig. 1. Picosecond spectrochronograph for studying time resolved emission spectra. $\mathrm{L}$ - lens; NC - nonlinear crystal for second harmonic generation; F - filters; K - sample; SC - synchroscan streak camera; D - photodiode; SYNC - synchronization unit; DRIV - streak camera driver.

was used. Fluorescence was viewed at an angle of $\sim 90^{\circ}$ to the exciting light direction in a reflection mode. The average exciting light density was changed with the help of gray filters and checked by a radiometer NRC Model 880 , or a calibrated photoelement. The same detector was used to measure continuous light intensity in measurements of $\varphi$ and $\mathrm{P}^{+} / \mathrm{P}_{0}$. The latter parameter was measured as a normalized photobleaching at $865 \mathrm{~nm}$ with a double-beam differential spectrophotometer. The $\varphi$ measurements were made with an Aminco-Bowman spectrofluorimeter [5]. All fluorescence decay curves were treated as a sum of two exponentials taking into account the apparatus response.

\section{Results}

\subsection{Light-intensity dependence of $R$. rubrum fluorescence lifetime.} Fluorescence decay curves of $R$. rubrum chromatophores excited by $375 \mathrm{~nm}$ light pulses of low $\left(6 \cdot 10^{5}\right.$ quanta $/ \mathrm{cm}^{2} /$ pulse $)$ and saturating $\left(5 \cdot 10^{7}\right)$ intensities are shown in Fig. 2, $a$. Both experimental curves are well approximated by a single exponential component (the same is true of intermediate intensities), and 1/e time, $\tau$, is equal to $\tau^{\mathrm{min}}=50 \mathrm{ps}$ for low, and $\tau^{\max }=190 \mathrm{ps}$ for saturating light. This agrees well with earlier data $[1,5]$. Repeated measurements with a given sample gave the values that agree within $10 \%$ (including day-to-day variations), but sample-tosample variations were up to $40 \%$ (see Fig. 3). The measured lifetime in one of the samples is presented in Fig. 4 (curve 2) as a function of average exciting light density. The results of parallel measurements of $\varphi$ and $\mathrm{P}^{+} / \mathrm{P}_{0}$ dependences on continuous light intensity for the same sample are also plotted in Fig. 4. It can be seen that as the RCs turned into the closed state, $\tau$ and $\varphi$ increased nearly parallel. Maximal increase 

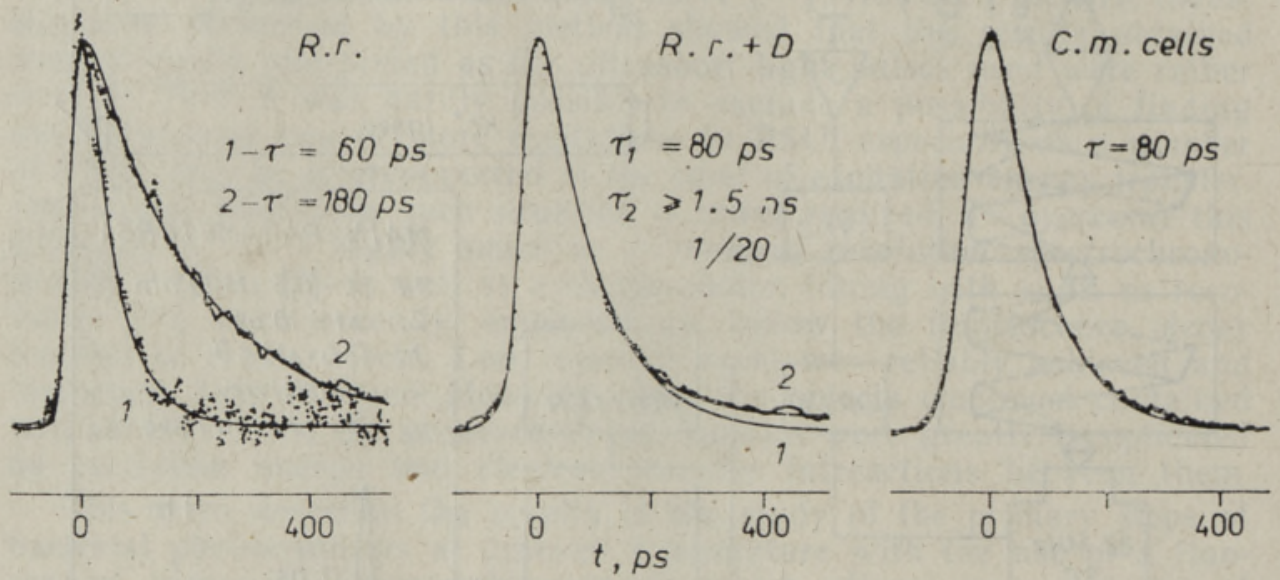

Fig. 2. $a$ - the kinetics of fluorescence decay of $R$. rubrum chromatophores at $900 \mathrm{~nm}$ (excitation wavelength $375 \mathrm{~nm}): 1-$ low, $2.5 \cdot 10^{-5} \mathrm{~W} / \mathrm{cm}^{2}$, exciting light density, minimal fluorescence level; 2 - saturating, $2 \cdot 10^{-3} \mathrm{~W} / \mathrm{cm}^{2}$, light density, maximum fluorescence level; $5 \cdot 10^{-5} M$ TMPD added. $b$ - fluorescence decay of $R$. rubrum at $900 \mathrm{~nm}$ in the presence of $10^{-3} \mathrm{M} \mathrm{Na}_{2} \mathrm{~S}_{2} \mathrm{O}_{4}: 1-$ a single-exponential calculated response with $\tau=80 \mathrm{ps} ; 2$ - two-exponential approach with amplitude ratio $A_{2} / A_{1}=$ $=1 / 20$; exciting light density $5 \cdot 10^{-3} \mathrm{~W} / \mathrm{cm}^{2}$ at $\lambda=800 \mathrm{~nm}$. $c-$ fluorescence decay kinetics of Chr. minutissimum cells at $920 \mathrm{~nm}$; excitation wavelength $750 \mathrm{~nm}$, light density $3 \cdot 10^{-3} \mathrm{~W} / \mathrm{cm}^{2}$. Dotted curves are experimental, continuous ones are the calcu-

lated fluorescence responses.

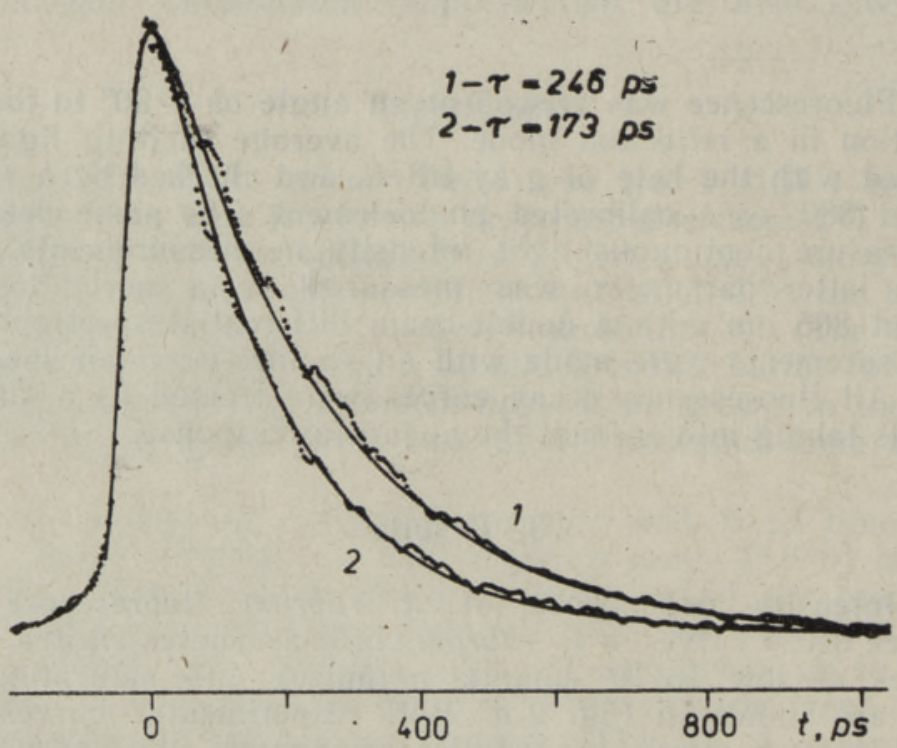

Fig. 3. The kinetics of fluorescence decay of two different preparations of $R$. rubrum chromatophores under excitation with $800 \mathrm{~nm}$ exciting light of saturating density, $2 \cdot 10^{-3} \mathrm{~W} / \mathrm{cm}^{2}$,

Continuous and dotted curves are the same as in Fig. 2.

in $\tau$ observed by us was $3-4$ times. Above the saturating light intensity level (intensities up to $3 \mathrm{~W} / \mathrm{cm}^{2}$ were employed for $\lambda=750 \mathrm{~nm}$ ), $\tau^{\max }$ did not change. This means that neither singlet-singlet nor singlet-triplet annihilation took place in our experiments. 


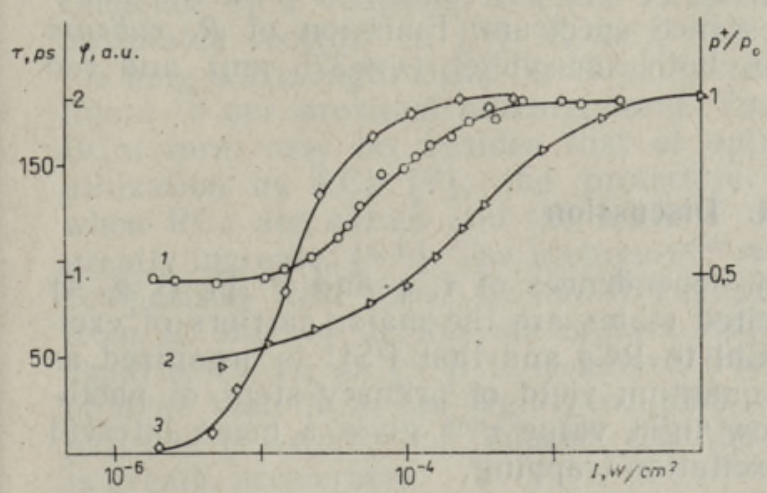

Fig. 4. Fluorescence yield $\varphi(1)$ and lifetime $\tau$ (2) of $R$. rubrum chromatophores at $902 \mathrm{~nm}$ as a function of average exciting light density at $375 \mathrm{~nm}$; (3) the same for a portion of photooxidized reaction centres, measured as a normalized absorption change $\mathrm{P}+/ \mathrm{P}_{0}$ at $600 \mathrm{~nm}$. Actinic light with $\lambda \geqslant 700 \mathrm{~nm}$ was used in the latter case.

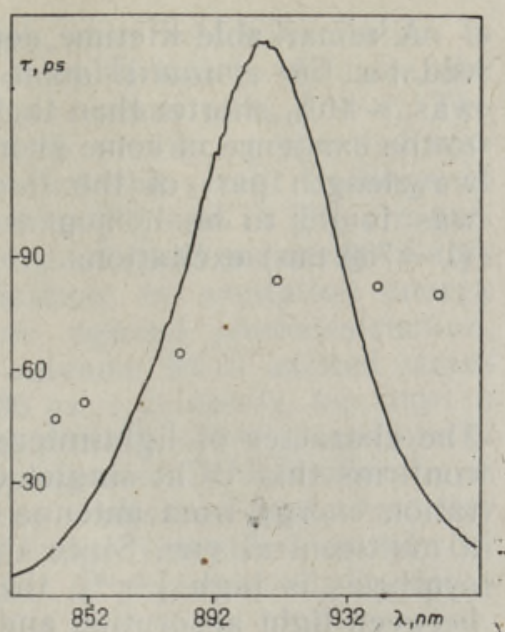

Fig. 5. Fluorescence spectrum and the dependence of fluorescence lifetime on emission wavelength for Chr. minutissimum cells. Fluorescence spectrum was measured in $1 \mathrm{~cm}-$ cell, optical density at $\lambda=365 \mathrm{~nm}$ was 0.2 . Lifetimes. were measured with $755 \mathrm{~nm}$ exciting light of density, $1 \mathrm{~W} / \mathrm{cm}^{2}$.

3.2. Long-lived nanosecond components in the emission of $R$. rubrum. Under certain conditions, together with the picosecond component of the emission described above, a nanosecond one was also observed. Twoexponential decays were detected for $R$. rubrum in the following cases:

(1) Chromatophore suspensions in the presence of $10^{-3} M \mathrm{Na}_{2} \mathrm{~S}_{2} \mathrm{O}_{4}$ (Fig. 2,b) ;

(2) Chromatophore suspensions after addition of reducing agents, such as sodium ascorbate, $2 \cdot 10^{-3} \mathrm{M}$, or mercaptonol, $10^{-3} \mathrm{M}$ and $\mathrm{N}, \mathrm{N}$, $\mathrm{N}^{\prime}, \mathrm{N}^{\prime}$-tetramethyl-p-phenylendiamine (TMPD). TMPD concentration was varied in the range of $5 \cdot 10^{-6}-5 \cdot 10^{-4} \mathrm{M}$ in order to obtain a necessary shift of the light intensity curves to higher intensities. These TMPD additions have no noticeable effect on the measured value of $\tau$ or the character of fluorescence decay when reducing agents were absent in the measuring solution;

(3) Intact cells of $R$. rubrum without any additions.

In all cases the lifetime of the second component was about 2 ns and its relative amplitude was less than ten per cent. The lifetime of the shorter component does not change substantially in any samples.

3.3. Fluorescence lifetime of purple bacteria as a function of excitation and emission wavelength. Such measurements are especially informative when a possibility of selective excitation of an appreciable part of RCs can be realized. Three excitation wavelengths were used in our experiments: (1) $\lambda=375-378 \mathrm{~nm}$, which excites antenna BChl (RC absorption is negligible); (2) $\lambda=798-800 \mathrm{~nm}$, at this wavelenght RCs in $R$. rubrum absorb more than half of the exciting light; (3) $\lambda=760 \mathrm{~nm}$, which excites primarily RC bacteriopheophytine. Fluorescence decay curves for all these wavelengths were superimposible both for low and saturating light intensities. A one-exponential fluorescence decay of Chr. minutissimum cells (Fig. 2,c) was also independent of the excitation wavelengths. 
A remarkable lifetime dependence on emission wavelength was observed for Chr. minutissimum (Fig. 5): $\tau$ for the short wavelength range was $\sim 40 \%$ shorter than that for the long wavelength range, which points to the existence of some short-lived $(\tau \sim 10 \mathrm{ps})$ component $(\mathrm{s})$ at the shortwavelength part of the fluorescence spectrum. Emission of $R$. rubrum was found to be homogeneous both for violet $(\lambda=375 \mathrm{~nm})$ and red $(\lambda=760 \mathrm{~nm})$ excitations.

\section{Discussion}

The character of light-intensity dependences of $\tau, \varphi \cdot$ and $\mathrm{P}+/ \mathrm{P}_{0}$ (Fig. 4) confirms that BChl singlet excited states are the major carriers of excitation energy from antenna BChl to RCs and that PSU is organized as a multicentral one. Since the quantum yield of primary steps of photosynthesis is high $\left[{ }^{15,16}\right]$, the low light value $\tau^{\text {min }}$ gives a mean interval between light absorption and excitation trapping.

Two extreme cases are distinguished depending on what is the bottleneck of the whole process: diffusion of excitations from antenna to RC (efficiency of excitation trapping by RC from the first visit is high) or the rate of the primary charge separation process (excitation visits RC many times before trapping). There has been no unequivocal evidence of whether diffusion or trap-limited migration is realized in purple bacteria. Fluorescence lifetime measurements under conditions of selective excitation of $\mathrm{RC}$ or of antenna $\mathrm{BChl}$ may solve the problem, provided exciting light intensity is sufficiently low [ $\left.{ }^{17}\right]$.

In our experiments with $R$. rubrum chromatophores were selectively excited by light with $\lambda=798,758$ and $375 \mathrm{~nm}$. The fact that fluorescence decay curves for these wavelengths were superimposible shows that, no matter what is primarily excited, RC or antenna BChl, the decay of excitations proceeds in the same way. This means that equilibrium distribution of excitations between RC and antenna BChl takes place before excitation is irreversibly trapped. In the alternative case $\tau^{\text {min }}$ should be shorter when part of excitation quanta is absorbed directly by RCs. Thus, in $R$. rubrum a purely trap-limited case of excitation energy migration is realized. In this case, $\tau^{\min }$ is simply related to $\tau_{e}$, in situ charge separation lifetime, namely $\tau_{e}=\tau^{\min } / N \quad\left[{ }^{18}\right]$, where $N$ is the number of antenna BChl molecules per RC. Since in our $R$. rubrum chromatophore preparations $N$ was equal to $35-40, \tau_{e}$ should be equal to $1-2$ ps. In case of trap-limited migration, the pairwise jump time $\tau_{j}$ between adjacent BChl molecules should be approximately an order of magnitude less than $\tau_{e}$, i. e. of the order of $10^{-13} \mathrm{~s}$.

This time is rather short in the view of the known data on PSU organization in the photosynthetic membranes. Namely, it is believed that BChl molecules $\mathrm{B}_{880}$ of $R$. rubrum as well as $\mathrm{B}_{860}$ of Rhodopseudomonas sphaeroides R-26 are arranged as dimers bound to hydrophobic proteins with a molecular weight between 10,000 and 20,000 [19]. Taking into account the size of these pigment-protein globules, an average intermolecular distance between the chromophores bound to adjacent globules, should be about $20 \AA$ or larger. According to Förster's formula: $\tau_{j}=\tau_{0}\left(R / R_{0}\right)^{6} \cdot q^{-1}\left(\tau_{0} \simeq 18\right.$ ns is the intrinsic BChl lifetime, $R_{0}$ Förster's radius, equal for $\mathrm{BChl}$ to $\left.80-90 \AA{ }^{8}\right]$, q, the number of nearest neighbour acceptors), $\tau_{j}$ for such intermolecular distances should be not shorter than several picosecond. We believe that the apparent contradiction we come to is due to the fact that fast excitonic exchange between $\mathrm{RC}$ and antenna BChl holds not for a whole PSU, but between RC and a small limited number of $\mathrm{BChl}$ molecules adjacent to it. These molecules form a 
«proximal»; tightly coupled with RC antenna, over which excitation is delocalized during the charge separation process. If this is the case, the above estimations would give somewhat larger values of $\tau_{e}$ and $\tau_{j}$. The existence of a coupling antenna complex with similar properties was postulated recently in $\left[{ }^{20}\right]$. It may well be that the recent findings of the long wavelength BChl forms of $R$. rubrum in $\left[{ }^{21}\right]$ and in $\left[{ }^{22}\right]$ are pertinent to our proximal antenna form. The physiological meaning of this $\mathrm{BChl}$ form may be, besides that of optimization of excitation energy utilization by $\mathrm{RCs}\left[{ }^{23}\right]$, the protective role against photodestruction, when RCs are closed and the lifetime of antenna BChl excited states greatly increase $\left[{ }^{5,24}\right]$. The lifetime $\tau^{\max } \approx 200 \mathrm{ps}$ is, evidently, too short in comparison with those for RC-free pigment-protein antenna complexes from $R$. rubrum or RC-less mutant Rps. sphaeroides PM-8 where $\tau$ is equal to $1-1.5 \mathrm{~ns}\left[{ }^{5,8}\right]$. It is known from the studies on photochemistry of dyes that, if in the tightly coupled molecular complex one of the partners is oxidized or reduced, and the other is photoexcited, its decay is greatly accelerated.

In conclusion, our data are summarized as the following scheme of structure-function organization of excitation energy transfer and trapping in $R$. rubrum. Several $(4-10)$ RCs are interconnected with each other via their proximal antenna BChl, which form, together with adjacent $B_{88_{0}}$ molecules, photosynthetic domain. Excitation from $B_{880}$ quickly reach the proximal antenna and then $\mathrm{RC}$, but since the efficiency of trapping from the first visit is low and interaction inside RC-proximal antenna complex is high, excitation remains in this complex during $50-70$ ps until trapped by a RC. As RCs become closed by photooxidation, excitation lifetime progressively increases, since there is now a larger number of $\mathrm{BChl}$ molecules of the proximal antenna per open RC. The data supporting the above scheme, which were recently obtained in $\left[{ }^{21}, 22\right]$ show that in $R$. rubrum there is a minor (3-5 molecules per RC) torm of antenna $\mathrm{BChl}$ some $10-12 \mathrm{BChl}$ molecules. Taking into account these data, $\tau_{e}$ may be estimated as $10-20 \mathrm{ps}$, which is several times larger than $\tau_{e}$ values measured by absorption spectroscopy for isolated RCs $\left[{ }^{25}\right]$.

In the light of the results obtained in this work it becomes clear why inconsistencies in $\tau$ and $\varphi$ dependences on exciting light intensity are encountered when these are compared for low-intensity $\mathrm{CW}$ picosecond pulse and relatively high-intensity single-pulse picosecond excitations. Firstly, the results at equal pulse (not average) energy should be compared. Secondly, in the case of single-pulse excitation quanta come to a photosynthetic domain almost simultaneously, and when excitation light density is low enough (less than one quantum per photosynthetic domain), all quanta are localized in the RC-proximal antenna complex until excitation trapping occurs. At higher pulse energies, besides trapping, efficient annihilation due to rather strong excitonic coupling between $\mathrm{BChl}$ molecules of the proximal antenna takes place. As a result, q will be constant when the number of quanta/domain $\leqslant 1$, and then decrease $\left[{ }^{8}\right]$. Nearly the same is true with lifetime dependence on excitation intensity. In the case of recurrence excitation with pulse-sequence period less than biochemical recovery time of the PSU as well as of continuous excitation the effect of excitation accumulation will work. As a result, already at relatively low pulse intensities the rise of quantum yield and lifetime is observed which saturates at higher intensities.

The nature of nanosecond components in the emission of purple bacteria as well as the Chr. minutissimum emission heterogeneity, will be discussed elsewhere. 


\section{Conclusions}

1. Employment of a new experimental technique, picosecond spectrochronography, made it possible to measure, for the first time, the fluorescence kinetics of purple bacteria with picosecond resolution and average excitation light density close to natural.

2. The whole $\tau$ light-intensity curve was followed from low (RCs open) to saturating light, and the time from light absorption to excitation trapping was measured to be $50 \pm 10$ ps. It is shown that $\tau$ and $\varphi$ increase in parallel as RCs turn into the closed state.

3. Selective excitation with light, absorbed by RCs, or by those absorbed by antenna BChl, shows that excitation energy transfer in $R$. rubrum is a trap-limited rather than a diffusion-limited process.

4. The time of primary charge separation in situ was determined to be in the range of $10-20 \mathrm{ps}$, and the pairwise jump time of excitation energy transfer was in the range of picoseconds.

5. To reconcile the data obtained with the known data on the structure of the photosynthetic apparatus, it is necessary to propose the existence of a proximal, tightly coupled with RCs antenna complex, distinct from the major $\mathrm{B}_{880}$ one, which includes several BChl molecules.

6. The emission of $R$. rubrum was found to be spectrally homogeneous, while those of Chr. minutissimum was inhomogeneous.

Acknowledgements. The authors are indebted to Profs K. K. Rebane and A. Yu. Borisov for valuable discussions and support, to Dr. S. G. Kharchenko for preparation of chromatophores.

\section{REFERENCES}

1. Borisov, A. Yu., Godik, V. I. Biochim. Biophys. Acta, 301, 227-248 (1973).

2. Knox, R. S. In: Bioenergetics of Photosynthesis (Ed. Govindjee), Chp. 4, New York, Academic Press, (1975).

3. Rubin, A. B. Photochem. Photobiol., 28, 1021-1040 (1978).

4. Borisov, A. Yu., Godik, V. I. Biochim. Biophys. Acta, 223, 441-443 (1970).

5. Godik, V. I., Borisov, A. Yu. FEBS Lett., 82, 355-358 (1977).

6. Sebban, P., Moya, I. Biochim. Biophys. Acta, 722, 436-442 (1983).

7. Paschenko, V. Z., Protasov, S. P., Rubin, A. B., Timofeev, K. N., Zamazova, L. M., Rubin, L. B. Biochim. Biophys. Acta, 408, 143-153 (1975).

8. Campillo, A. J., Hyer, R. C., Monger, T. G., Parson, W. W., Shapiro, S. L. Proc. Nat. Acad. Sci. USA, 74, 1997-2001 (1977).

9. Freiberg, A. M., Timpmann, K. E., Tamkivi, R. P., Avarmaa, R. A. ENSV TA Toim. Füüs. Matem., 31, 200-207 (1982).

10. Haehnel, W., Nairn, J. A., Reisberg, P., Sauer, K. Biochim. Biophys. Acta, 680, $161-173$ (1982).

11. Nazarenko, A. V., Samuilov, V. D., Skulachev, V. P. Biokhimiya 36, $780-782$ (1971).

12. Freiberg, A., Saari, P. IEEE J. Quant. Electron., QE-19, 622-630 (1983).

13. Saari, P., Aaviksoo, J.; Freiberg, A., Timpmann, K. Opt. Commun., 39, 94-98 (1981).

14. Freiberg, A., Raidaru, A., Anijalg, A., Timpmann, K., Kukk, P., Saari, P. ENSV TA Toim. Füüs. Matem., 29, 187-194 (1980).

15. Loach, P. A., Secura, D. L. Photochem. Photobiol., 1, 2642-2649 (1968).

16. Barsky, E. L., Borisov, A. Yu. J. Bioenerg., 2, 275-280 (1971),

17. Pearlstein, R. M. Photochem. Photobiol., 35, 835-844 (1982).

18. Montroll, E. W. Proc. Symp. Appl. Math. 16, 193-220 (1964).

19. Sauer, K., Austin, L. Biochemistry, 17, 2011-2019 (1978).

20. van Grondelle, R., Daysens, L. N. M. Plant Physiol, 65, 751-754 (1980).

21. Borisov, A. Yu., Gadonas, R. A., Danielius, R. V., Piskarskas, A. S., Razjivin, A. P. FEBS Lett., 138, 25-28 (1982).

22. Gómez, I., Sieiro, C., Ramirez, J. M., Gomez-Amores, S., del-Campo, F. F. FEBS - Lett., 144, 117-120 (1982). 
23. Fetisova, Z. G., Fok, M. V., Borisov, A. Yu. Molek. Biol., 17, 437-445 (1983).

24. Heathcote, P., Clayton, R. K. Biochim. Biophys. Acta, 459, 506-515 (1977).

25. Holten, D., Hoganson, C., Windsor, M. W., Schenck, C. C., Parson, W. W., Migus, A., Fork, R. L., Shank, C. V. Biochim. Biophys., Acta, 592, 461-477 (1980).

\section{Moscow State University}

Academy of Sciences of the Estonian SSR, Institute of Physics

Received

July 18,1983

Valentina GODIK, A. FREIBERG, K. TIMPMANN

\section{VALGUSENERGIA LOKSUSTUSMEHHANISMIDE UURIMINE FOTOSONTEESIVATE BAKTERITE REAKTSIOONITSENTRITES PIKOSEKUNDILISE SPEKTROKRONOGRAAFIA ABIL}

Purpurbakterite bakterklorofülli (BChl) fluorestsentsi eluiga $(\tau)$ mõõdeti pikosekundilise fluorestsentsspektrokronograafi abil, mida iseloomustab suur tundlikkus ja kõrge ajaline ning spektraalne lahutusvõime. Onnestus registreerida Rhodospirillum rubrum'i kromatofooride $\tau$ sõltuvus valgustatusest madalate (peaaegu kõik reaktsioonitsentrid (RC) avatud) ja ka küllastavate intensiivsuste piirkonnas. Tulemusena määrati ajaintervall, mis kulub valguskvandi neeldumisest BChl-s ergastuse lōksustumiseni RC-s. See aeg on $50 \pm 10$ ps. $R$. rubrum'i kromatofooride selektiivne ergastamine valgusega, mis neeldub põhiliselt $\mathrm{RC}$-s $(\lambda \simeq 800 \mathrm{~nm})$ või antenni BChl-s $(\lambda=370-380 \mathrm{~nm})$, võimaldas näidata, et valgusergastuse ülekanne ei ole limiteeritud mitte ergastuse difusiooni poolt antennis, vaid sõltub lōksustumisest RC-s. Esmane laengute eraldumise aeg in situ on saadud tulemuste pōhjal $10-20$ ps.

\section{Валентина ГОДИК, А. ФРЕЙБЕРГ, К. ТИМПМАНН \\ ИЗУЧЕНИЕ МЕХАНИЗМОВ ЗАПАСАНИЯ ЭНЕРГИИ СВЕТА РЕАКЦИОННЫМИ ЦЕНТРАМИ ФОТОСИНТЕЗИРУЮЩИХ БАКТЕРИЙ МЕТОДОМ ПИКОСЕКУНДНОИ СПЕКТРОХРОНОГРАФИИ}

Времена жизни флуоресценции $\tau$ бактериохлорофилла (БХл) пурпурных бактерий измерены на пикосекундном флуоресцентном спектрохронографе. Высокая чувствительность, а также высокое временное и спектральное разрешение спектрохронографа піри низкой энергии возбуждающих импульсов позволили снять световую зависимость $\tau$ для хроматофоров Rhodospirillum rubrum от низкой (почти все реакционные центры (РЦ) открыты) до насыщающей интенсивности. По этим данным определен временной интервал между поглощением кванта света молекулой БХл и захватом возбуждения РЦ, равный $50 \pm 10$ пс. Селективное возбуждение хроматофоров $R$. rubrum светом, поглощенным в значительной доле РЦ $(\lambda \simeq 800$ нм) либо БХл антенны $(\lambda=370-380$ нм $)$, показало, что процесс переноса энергин лимитируется захватом, а не диффузней возбуждений по антенне. Время первичного разделения зарядов in situ составляет, согласно полученным данным, $10-20$ пс. 